\title{
Economics of marketing and processing of aonla in district Pratapgarh, Uttar Pradesh
}

\section{J. RAI, SHESH PRATAP SINGH AND ARUN KUMAR SINGH}

Received : 22.02.2016; Revised : 27.08.2016; Accepted : 14.09.2016

\begin{abstract}
The study was carried out in Sadar block of district Pratapgarh in Uttar Pradesh with 30 aonla growers ( 8 marginal, 6 small and 16 big respondents) selected randomly with six villages of the selected block. The over all plantation cost of one hectare aonla was worked out of Rs.47000 .The cost of of gestation period was calculated as Rs. 78876.60 for six years of gestation period. On an average cost of aonla production per hectare came to Rs.27386.02. The highest cost intake of 6-12 years orchard was worked out as Rs.33272.08/ha, while lowest cost was observed in 24 years and above aged orchard as Rs.23836.00/ha. The input-output analysis shows that aonla crop fetched on an average 5.45 times more return on investment of Rs. 1. Problems of insect-pest and diseases, lack of plant protection measures and lack of skilled human resource at peak season was observed as main constraints in the study area.
\end{abstract}

KEY WORDS : Cost of production, Plantation cost, Gestation period cost, Cost-A, B, C

How to cite this paper : Rai, J., Singh, Shesh Pratap and Singh, Arun Kumar (2016). Economics of marketing and processing of aonla in district Pratapgarh, Uttar Pradesh. Internat. J. Com. \& Bus. Manage, 9(2) : 209-213, DOI: 10.15740/HAS/IJCBM/9.2/209-213.

\section{MEMBERS OF THE RESEARCH FORUM}

Correspondence to:

J. RAI, Department of Agricultural Economics and Statistics C.S. Azad University Agriculture and Technolgy, KANPUR (U.P.) INDIA

\section{Authors' affiliations:}

SHESH PRATAP SINGH, Department of Agricultural Economics and Statistics, C.S. Azad University Agriculture and Technolgy, KANPUR (U.P.) INDIA

ARUN KUMAR SINGH, Krishi Vigyan Kendra, ETAWAH (U.P.) INDIA 